\title{
Erratum to: Smartphone apps for orthopaedic sports medicine - a smart move?
}

Seng Juong Wong ${ }^{1 *}$, Greg A. Robertson ${ }^{2}$, Katie L. Connor ${ }^{3}$, Richard R. Brady ${ }^{4}$ and Alexander M. Wood ${ }^{5}$

\section{Erratum}

Since the publication of this article [1], we have been made aware that the declaration of the competing interests of one of the authors was omitted. The 'Competing interests' section should have read as follows:

"Richard Brady is the owner of researchactive.com Ltd., a company that provides websites, and develops app and social media solutions for the health care market. No external company was involved in the drafting, editing or analysis within this paper."

\section{Author details}

${ }^{1}$ University of Edinburgh, College of Medicine and Veterinary Medicine, 7/3 West Nicolson Street, Edinburgh EH8 9DA, UK. ${ }^{2}$ Department of Trauma and Orthopaedics, Royal Infirmary Edinburgh, Edinburgh, UK. ${ }^{3}$ Department of General Surgery, Kirkaldy, Fife, UK. ${ }^{4}$ Department of Colorectal Surgery, Western General Hospital, Edinburgh, UK. ${ }^{5}$ Department of Orthopaedics, Wansbeck Hospital, Ashington, UK.

Published online: 20 November 2015

\section{Reference}

1. Wong SJ, Robertson GA, Connor KL, Brady RR, Wood AM. Smartphone apps for orthopaedic sports medicine - a smart move? BMC Sports Sci Med Rehab. 2015;7:23.

\footnotetext{
* Correspondence: S1366830@sms.ed.ac.uk

'University of Edinburgh, College of Medicine and Veterinary Medicine, 7/3
} West Nicolson Street, Edinburgh EH8 9DA, UK

Submit your next manuscript to BioMed Central and take full advantage of:

- Convenient online submission

- Thorough peer review

- No space constraints or color figure charges

- Immediate publication on acceptance

- Inclusion in PubMed, CAS, Scopus and Google Scholar

- Research which is freely available for redistribution

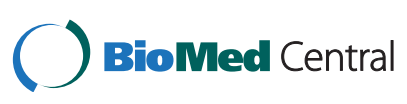

